${ }^{2}$ National Soll Tilth Laboratory, USDA-ARS, Ames, lowa, U S A

\title{
Spatial Variability of Rainfall at an Experimental Station in Niger, West Africa
}

\author{
M. V. K. Sivakumar' and J. L. Hatfield ${ }^{2}$ \\ With 8 Figures
}

Recelved October 14, 1988

Revised August 14, 1989

\begin{abstract}
Summary
Variability of rainfall in the semi-arid regions can cause problems in evaluating experimental trials To describe the spatial rainfall patterns over a large experimental station, rainfall was monitored during the 1986 and 1987 rainy seasons using 18 raingages over the 500 ha experimental station of ICRISAT Sahelian Center, in Niger, West Afnca Average relative vanability of individual rain storms, defined as the percentage deviation from the mean, vaned from 2 to $62 \%$, while the variability over the rainy season was $171 \%$ Isohyetal patterns of individual rain storms as well as seasonal totals showed distinct coherence in the spatial pattern over the station The effects of total volume, duration, direction and intensity of storms and the time of year on the spatial correlations were analyzed Storm value showed a large influence on the correlation decay with distance Correlations in the $W-E$ and $S W-N E$ directions were higher in comparison to those in the $\mathrm{N}-\mathrm{S}$ and $\mathrm{NW}-\mathrm{SE}$ directions Point rainfall measurements were better correlated with the network average rainfall than with the rainfall recorded at the meteorological station Vanograms among raingages revealed that the distance of independence was approximately $1000 \mathrm{~m}$ for almost all storms Use of a network of rangages over agncultural expenment stations reduces the average relative vanability of areal rainfall estumates and provides a means to develop simple relations for estumation of point rainfall for individual applications
\end{abstract}

\section{Introduction}

Temporal and spatial variability of rainfall is recognized as an important factor affecting regional crop productivity in the arid and semi-arid regions of the world. Despite such recognition, studies on spatial variability of rainfall are limited in comparsson to those concerning temporal variability. Quantitative description of the spatial variability of rainfall requires operation of concentrated raingage networks which are often not avalable.

Agnicultural experimental stations in the arid and semi-and regions vary in area from a few hectares to a few hundreds of hectares. It is common knowledge that crops, sown on the same day and managed in simular fashion through the season, give different yields depending upon the site where these experiments are conducted. Often the tendency is to ascribe such differences to varying soil types or soil fertility. However, spatial variability of rainfall cannot be ignored because a large proportion of the rainfall in the and and semiarid regions is produced in convective storms. Austin (1970) estimated the relative contribution of convective and stratiform lifting to the total precipitation at almost 100 per cent in the tropics and roughly 50 per cent in a temperate area. Sharon (1972) described the spatial variation associated with convective activity as "spottiness" of rainfall. Although spottuness of rainfall is generally recognized as a problem, scientists tend to rely upon rainfall data collected from a single meteorological observatory located at a convenient point in the 
station. This practice is partly due to lack of quantification of the nature of spatial variability of rainfall.

Spatial variability studies that have been conducted so far varied in spatial as well as temporal scales. Linsley and Kohler (1951) used a network of 55 raingages over an $570 \mathrm{~km}^{2}$ area. Huff and Shipp (1968) studied mesoscale spatial variability in East Central Illinois using a network of 49 recording raingages in a uniform pattern on an area of $1036 \mathrm{~km}^{2}$. Huff and Shipp (1969) studied storm, monthly and seasonal rainfall amounts and showed the effect of rain type, synoptic storm type and other factors on spatial correlations.

Even at a smaller scale of few $\mathrm{km}^{2}$ which is typical of large experimental stations in tropical regions, spatial variability of rainfall is generally observed, but no efforts have been made to quantify this variability. At stations with low mean annual rainfall, such variability can cause prob. lems in the evaluation of experimental trials.

The objectives of this study, therefore, were:

a) To study the nature of spatial variability of individual rain storms, monthly and seasonal totals, using a dense network of raingages at a large experimental station in Niger.

b) To evaluate the effect of storm characteristics on the spatial variability of individual storms and to determine the spatial structure of each storm.

c) To assess the extent to which data from a single meteorological observatory could be relied upon for research applications over a large experimental station.

\section{Methods}

\section{I Raingage Network}

The raingage networks were installed at the ICRISAT Sahelian Center, located at Satore $\left(13^{\circ} 15^{\prime} \mathrm{N}, 2^{\circ} 18^{\prime} \mathrm{E}\right)$ in Niger. Average elevation of the experimental station is about $240 \mathrm{~m}$ and terrain is flat covering an area of $500 \mathrm{ha}$.

Diem type raingages, mounted at $2 \mathrm{~m}$ above the soil surface were used. Raingage placement was dictated to a large extent by the field layout as the roads had already been laid out. It was also difficult to follow a precise grid pattern since raingages could not be within the experimental fields. To obtain a good sample of the rainfall, eighteen raingages were installed principally along the
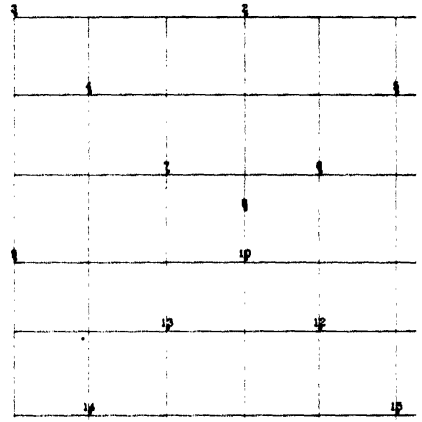

ip

Fig. 1. Map of raingage network at the ICRISAT Sahelian Center, Sadore, Niger

NW-SE and SW-NE diagonals at field intersections (roughly at a $500 \mathrm{~m}$ linear distances) and in the middle of $\mathrm{E}-\mathrm{W}$ and $\mathrm{N}-\mathrm{S}$ boundaries (Fig. 1).

Before installation, all raingages were calibrated against a tipping bucket raingage at the meteorological station.

There were 33 rain events in 1986 and 30 in 1987. After each event, rainfall from all the raingages was recorded and the gages were immediately emptied.

\subsection{Analytical Procedures}

A storm was defined as a rainfall period separated from preceding and succeeding rainfall by $6 \mathrm{~h}$ or more (Huff and Shipp, 1969). For each storm event, mean and standard deviation over the eighteen raingages were computed. Correlation coefficients among raingages were analyzed using untransformed data as described by Huff and Shipp (1969). To obtain correlation coefficients in different directions i.e., W-E, N-S, NW-SE, SW - NE etc., rows of raingages along these axes were used.

To determine the effects of storm duration and storm intensity on spatial correlations, rainfall data recorded at 1-minute intervals at an auto- 
matic weather station located in the center of the experiment station at Sadore near raingage 8 (Fig. 1) were used.

Spatial relative variability for each rain storm was computed using the definition of Conrad and Pollack (1950) as,

$V=100(S / M)$,

where $V$ is the relative variability in per cent, $M$ is the network average storm rainfall and $S$ is the absolute average deviation from the mean.

Each individual storm event was analyzed for spatial variability patterns with the techniques described by Vieira et al. (1983). A semivariogram was calculated for each storm to quantify the distance at which each raingage became independent of another raingage. For each storm the range, the distance at which the variance exceeded the population variance, was computed. These analyses were used to determine the spatial structure of each storm and to evaluate whether any unique pattern existed among the raingages.

\section{Results and Discussion}

\subsection{Variability of Rainfall}

Individual storms:

To determine spatial variability patterns, data for individual storms were used to map isohyetal pat-

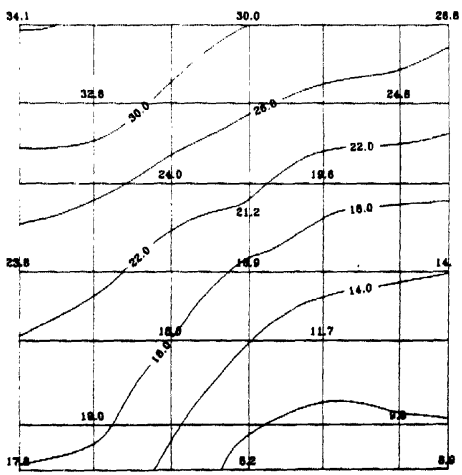

Fig. 2. Isohyetal pattern of storm rainfall on 22 July, 1986 at the ICRISAT Sahelian Center, Sadore, Niger

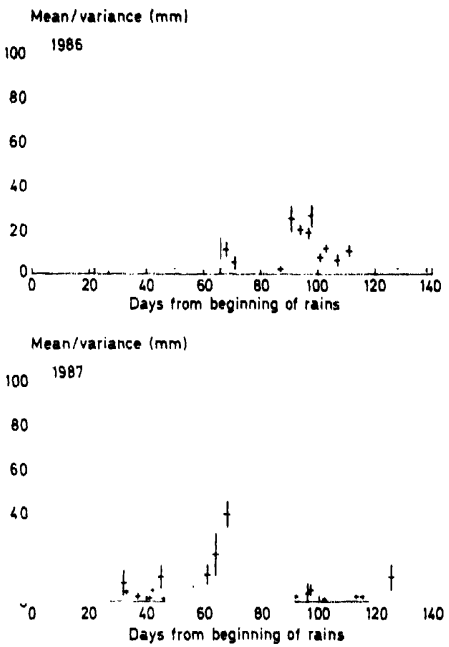

Fig. 3. Mean rainfall over the network and the variance for individual rain storms during 1986 and 1987 at the ICRISAT Sahelian Center, Sadore, Niger

terns for each storm as well as seasonal totals. In general, the spatial variability for individual storms was larger than for the seasonal totals. For example, the isohyetal pattern of storm rainfall on 22 July 1986 at Sadore (Fig. 2) shows that rainfall ranged from $34 \mathrm{~mm}$ in the northwest corner to $8.9 \mathrm{~mm}$ in the southeast corner; in contrast $21.2 \mathrm{~mm}$ of rainfall was received at the meteorological station. Average relative variability for 63 rainstorms during 1986 and 1987 at Sadore ranged from 2 to $62 \%$ with a standard error of $1.68 \%$.

Figure 3 shows the mean rainfall and variance over the 18 raingages, for each rainstorm in 1986 and 1987. In 1986, most of the rainstorms at the beginning of the rainy season exhibited a large variance while in 1987 the pattern was reversed with mid-season and late rain storms showing the largest variance.

Monthly and seasonal totals:

While the variability of individual storms was large, for monthly and seasonal rainfall totals vari- 
Table 1. Average Storm Volume and Average Relative Variability of Rainfall During the Rainy Season at the ICRISAT Sahelian Center, Sadore, Niger (standard errors are given in parenthesis)

\begin{tabular}{lll}
\hline Month & $\begin{array}{l}\text { Average storm } \\
\text { volume }(\mathrm{mm})\end{array}$ & $\begin{array}{l}\text { Average relative } \\
\text { variability }(\%)\end{array}$ \\
\hline June & $11.6( \pm 4.08)$ & $24.6( \pm 7.47)$ \\
July & $13.0( \pm 2.72)$ & $17.1( \pm 2.34)$ \\
August & $21.6( \pm 4.14)$ & $12.5( \pm 3.35)$ \\
September & $11.5( \pm 2.54)$ & $18.7( \pm 3.19)$ \\
Oetober & $13.3( \pm 2.55)$ & $19.9( \pm 0.40)$ \\
Rainy season & $14.9( \pm 1.71)$ & $17.1( \pm 1.69)$
\end{tabular}

ability decreased. Average storm volumes and average relative variability for different months during the rainy season and for the entire season are shown in Table 1. With increase in the average storm value from June to August, average relative variability decreased, and was $17.1 \%$ for the whole season.

Isohyetal pattern for the seasonal total rainfall during 1986 at Sadore (Fig. 4) shows a distinct trend with the maximum rainfall in the northwest corner and the minimum rainfall in the southeast corner of the station. At the meteorological station, the 1986 seasonal total rainfall was $552 \mathrm{~mm}$.
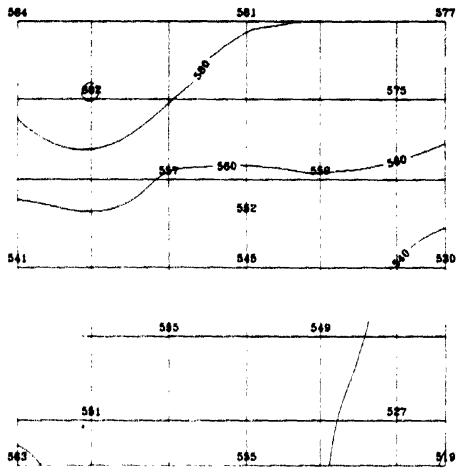

Fig. 4. Isohyetal pattern of seasonal total rainfall during 1986 at the ICRISAT Sahelian Center, Sadore, Niger

\subsection{Spatial Correlations}

Effects of volume, duration and intensity of storms and time of year:

In view of the observed variability in the isohyetal patterns for individual rainstorms, analyses were carried out to determine the influence of storm

\section{Awrage correlation oepffielont}

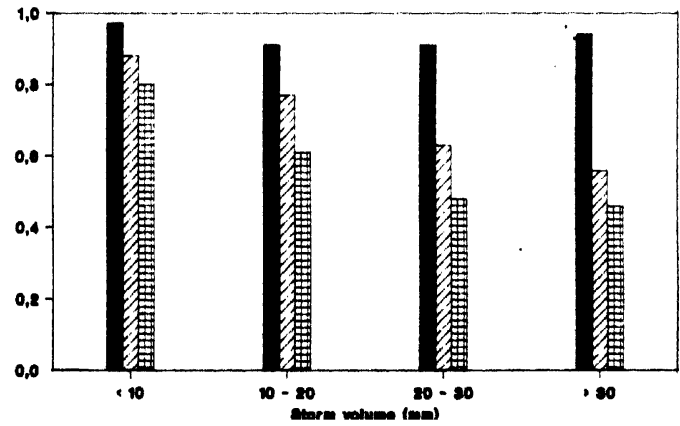

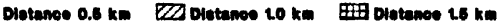

Fig. S. Effect of storm volume on the variation of the correlation coefficients of raingages located at different distances with the raingage located at the meteorological observatory at the ICRISAT Sahelian Center, Sadore, Niger 
characteristics (volume, duration, intensity and time of the year) on the spatial variability of rain. Correlation coefficients were computed relating the 17 raingages located over the station with the raingage situated at the meteorological observatory in the center of the station. Effects of different storm characteristics were compared with the decay of the correlation coefficient with distance.

Storm volume showed a large influence on the correlation decay with distance (Fig. 5). The reduction in the correlation coefficients with raingages located farther away from the meteorological observatory was least for the smallest storm volumes $(<10 \mathrm{~mm})$. This conclusion can also be drawn from Fig. 3, which shows that in general, rain storms with volumes greater than $20 \mathrm{~mm}$ had larger variances. This is in contrast to the conclusions of Huff and Shipp (1969), from a temperate region (Illinois, U.S.A.) that average precipitation within a sampling area has very little effect on point-to-point correlations. Their networks covered large areas of 1036 and $1425 \mathrm{~km}^{2}$ respectively and average spacing between raingages was $4.0 \mathrm{~km}$. Storm duration, storm intensity and time of the year had little effect on the correlation decay and virtually all correlation coefficients were greater than 0.9 .
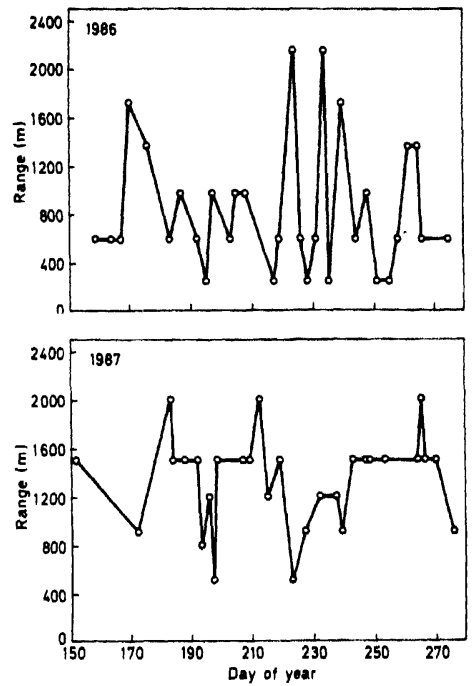

Fig. 6. Range of independence among raingages during 1986 at the ICRISAT Sahelian Center, Sadore, Niger

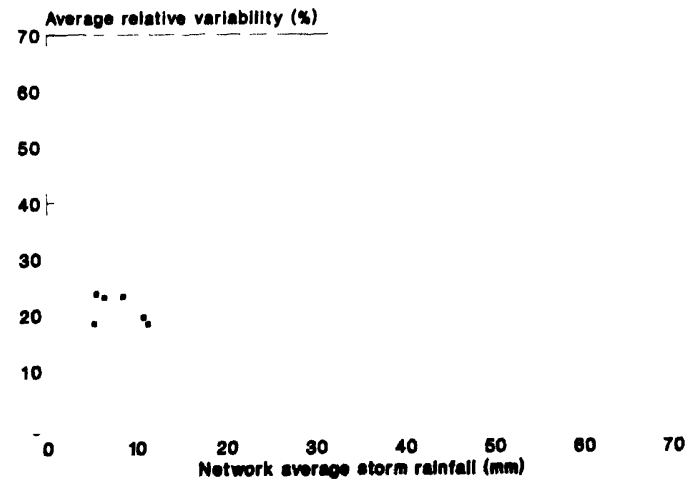

Fig. 7. Relationship between average relative variability and network average storm rainfall at the ICRISAT Sahelian Center, Sadore, Niger 


\subsection{Variograms}

Variograms were utilized to determine the distance among raingages at which there was no structure or independence within the population of raingages. The range, the distance of independence, as a function of DOY (day of year) is shown in Fig. 6. At Sadore, the range was greater than $500 \mathrm{~m}$ in 1986 and $1500 \mathrm{~m}$ in 1987 . This was typical for the majority of the storm events. The differences between years would suggest that the year-to-year variability is considerable and to reduce the variation among the grid points, a smaller grid spacing would be desirable. A nugget effect is defined as that condition in which the variation occurs within the smallest sampling interval. The range is determined from a curve of the variance calculated from each distance between sampling points. These was a small number of storms in which a nugget effect was observed, which implies that basically any spatial structure in the population would have occurred at a distance less than the smallest sampling interval. The range in both years was independent of the storm volume, which is encouraging because it shows that the raingage placement can be standardized within a large area without introducing bias into the data.

\subsection{Use of Network Average Rainfall}

The spatial variability of rainfall suggests that on large experimental stations in the semi-arid tropics, it will be necessary to consider installation of other raingages to supplement information from the common meteorological station in order to obtain an accurate spatial average. As shown in Fig. 5, factors such as storm volume affect the reliability of use of data from raingages located at some distance from a central raingage. In contrast, use of a network of raingages provide a reliable estimate of areal rainfall. The relationship between spatial relative variability and network average storm rainfall is shown in Fig. 7. Although there is some scatter, the data show that with higher storm volumes, use of a network can lower the average relative variability to values closer to $10 \%$.

Use of a network also provides a means to develop simple relationships to estimate rainfall at any given point in the network from the network average rainfall. Such a relationship can be expected to be stronger than the relationship between point rainfall and the rainfall recorded at the meteorological station. An example of these relationships is shown in Fig. 8 using data for low
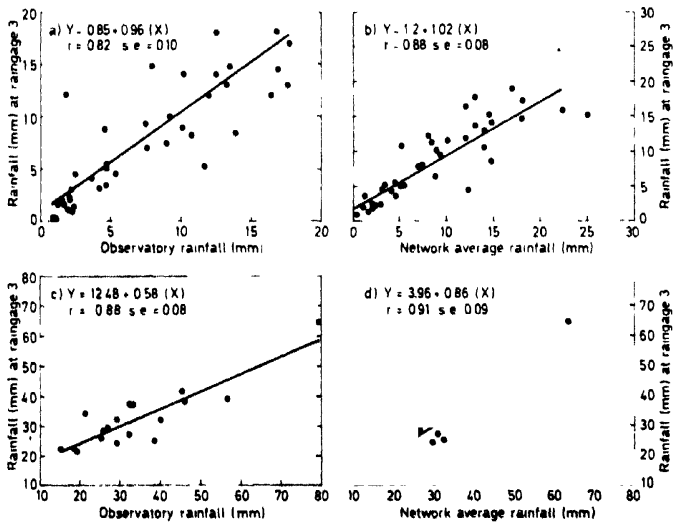

Fig. 8. Relationships between rainfall reconded at raingage 3, at the meteorological observatory, and network average rainfall. Relationships shown in (a) and (b) are for low volume rain storms, and in (c) and (d) are for the high volume rain storms 
and high volume storms for 1986 and 1987 . The $r$ values and scatter of data around the regression line suggests that point rainfall in a large experimental station is more closely related to the network average than to the rainfall recorded at the meteorological station.

Spatial patterns of rainfall in the semi-arid areas are not easily defined. There was no discernable pattern among all of the raingages among storms. This would suggest that a network of stations would be preferable in obtaining a mean for the experimental station.

\section{Conclusions}

Spatial variability of individual rain storms on large experimental stations in tropical regions is an important factor that cannot be ignored. Most experimental stations rely on data from a meteorological station for critical decisions concerning field operations and evaluation of experimental trials. After a long dry season, rains in the begin. ning of the rainy season are critical for stand establishment. In view of the spatial variability that characterizes the individual rain storms, use of rainfall data from meteorological observatory must be approached with caution. At Sadore the distance of independence among raingages was between 500 and $1500 \mathrm{~m}$ for the two years of study and was independent of storm volume. Raingage placement can be done in a systematic pattern to characterized the spatial average. Point rainfall over the experimental station relates better to the average of rainfall over such a network of rain- gages than to data from the meteorological station.

Data collected in this manner would be of use in comparing experimental trials and practices among years, particularly where soil water treatments are involved. The minimum distance between raingages recommended would be $500 \mathrm{~m}$. This would characterize all but a few isolated storm events.

Austin, P. M., 1970: Analysis of small-scale convection in New England. Proceedings of the 14th Conference on Radar Meteorology, Tucson, Arizona, 210-215.

Conrad. V., Pollack, L. W., 1950: Methods in Climatology. New York: Harvard University Press, 54-55.

Huff, F. A., Shipp. W. L., 1968: Mesoscale spatial variability in midwestern precipitation. J. Appl. Meteor., 7. 886-891.

Huff, F. A., Shipp, W. L., 1969 : Spatial correlations of storm, monthly and seasonal precipitation. J. Appl. Meteor., 8. 542-550.

Linsley, R. K., Kohler. M. A., 1951: Variations in storm rainfall over small areas. Trans. Amer. Geophys. Union., 32. 245-250.

Sharon, D., 1972: The spottiness of rainfall in a desert area. J. Hydrol., 17, 161-175.

Sharon, D., 1974: The spatial pattern of convective rainfall in Sukamaland, Tanzania: A statistical anaylsis. Arch. Met. Geoph. Biokl., Ser. B, 22, 201-218.

Vieira, S. R., Hatfield, J. L., Nieisen, D. R., Bigger, J. W., 1982: Geostatistical theory and application to variability of some agronomical properties. Hilgardia, 51 (3), 75 pp.

Authors' addresses: M. V. K. Sivakumar, International Crops Research Institute for the Semi-Arid Tropics (ICRISAT) Sahelian Center, B. P. 12404, Niamey, Niger, and J. L. Hatfield, National Soil Tilth Laboratory, USDA-ARS, 2150 Pammel Drive, Ames, lowa 50011, U.S.A. 